University of Nebraska - Lincoln

DigitalCommons@University of Nebraska - Lincoln

6-2004

\title{
Exotic Weed Invasion Increases the Susceptibility of Native Plants to Attack by a Biocontrol Herbivore
}

Tatyana A. Rand

University of Nebraska - Lincoln, tatyana.rand@ars.usda.gov

Svata M. Louda

University of Nebraska - Lincoln, slouda1@unl.edu

Follow this and additional works at: https://digitalcommons.unl.edu/bioscifacpub

Part of the Life Sciences Commons

Rand, Tatyana A. and Louda, Svata M., "Exotic Weed Invasion Increases the Susceptibility of Native Plants to Attack by a Biocontrol Herbivore" (2004). Faculty Publications in the Biological Sciences. 66.

https://digitalcommons.unl.edu/bioscifacpub/66

This Article is brought to you for free and open access by the Papers in the Biological Sciences at DigitalCommons@University of Nebraska - Lincoln. It has been accepted for inclusion in Faculty Publications in the Biological Sciences by an authorized administrator of DigitalCommons@University of Nebraska - Lincoln. 


\title{
EXOTIC WEED INVASION INCREASES THE SUSCEPTIBILITY OF NATIVE PLANTS TO ATTACK BY A BIOCONTROL HERBIVORE
}

\author{
TATyana A. RAnd ${ }^{1}$ And Svata M. Louda \\ School of Biological Sciences, University of Nebraska, Lincoln, Nebraska 68588-0118 USA
}

\begin{abstract}
Landscape change has great, yet infrequently measured, potential to influence the susceptibility of natural systems to invasive species impacts. We quantified attack by an invasive biological control weevil (Rhinocyllus conicus) on native thistles in relation to two types of landscape change: agricultural intensification and invasion by an exotic thistle, Carduus nutans, the original target of biological control. Weevil egg load was measured on native thistles in three landscape types: (1) agriculture dominated, (2) grassland dominated with exotic thistles, and, (3) grassland dominated without exotic thistles. We found no difference in egg load on native thistles within grassland landscapes without exotic thistles vs. within agricultural landscapes, suggesting that agricultural intensification per se does not influence levels of weevil attack. However, attack on the native Cirsium undulatum increased significantly (three- to fivefold) with increasing exotic thistle density. Within-patch exotic thistle density explained $>50 \%$ of the variation in both the intensity and frequency of weevil attack. Since $R$. conicus feeding dramatically reduces seed production, exotic thistles likely exert a negative indirect effect on native thistles. This study provides some of the first empirical evidence that invasion by an exotic plant can increase attack of native plants by shared insect herbivores.
\end{abstract}

Key words: apparent competition; associational susceptibility; biological control; insect herbivory; landscape change; plant invasion.

\section{INTRODUCTION}

Invasive species are a leading threat to the integrity of natural populations and communities (Wilcove et al. 1998, National Research Council 2002). While a landscape-scale approach to evaluating community susceptibility to colonization and impact by invasive species is likely to provide key insights, few studies have done this quantitatively (but see Smallwood 1994, Suarez et al. 1998, Higgins et al. 1999, Hobbs 2001). In this study, we examined the influence of landscape changes, including agricultural intensification and invasion by an exotic weed, on the susceptibility of native thistles to attack by an invasive biocontrol weevil.

Landscape structure can affect the movement and population dynamics of species and, thus, may influence invasion dynamics (With 2002). For example, land-use practices in the habitat matrix surrounding natural areas may promote large populations of exotic or weedy species, which then serve as sources of colonists into adjacent natural areas (Janzen 1983, Hobbs 2001). In contrast, natural areas surrounded by a highly inhospitable matrix may experience reduced rates of colonization by exotics, similar to isolated islands in biogeography theory (MacArthur and Wilson 1967). Previous studies have found reduced densities of herbivores in more isolated or fragmented habitats (Kruess and Tscharntke 1994, Steffan-Dewenter et al. 2001),

Manuscript received 18 April 2003; revised 12 August 2003; accepted 18 November 2003. Corresponding Editor: D. L. Urban.

${ }^{1}$ E-mail: tatyana_rand@ hotmail.com suggesting that plants may experience a relative refuge from their herbivores, including invasive insects, in fragmented landscapes. In our study system, the agricultural (crop) matrix is not suitable habitat for the biocontrol weevil, Rhinocyllus conicus, since it lacks host plants. Thus, we predicted that weevil densities would decrease with increasing amounts of agricultural habitat within the larger landscape, resulting in reduced attack on native thistles.

Susceptibility of native species to invasive species impacts may also be influenced by previous invasions. Areas that have been invaded by one species can be more or less susceptible to invasion by another species, depending on their interactive dynamics (Simberloff and Von Holle 1999). In plant-herbivore systems, the presence of an invasive host plant likely facilitates initial establishment of adapted exotic herbivores, which may ultimately negatively impact the plant population. This is the desired outcome of classical biological control (DeBach and Rosen 1990). However, in the absence of significant limitation by the insect, exotic plants may maintain insect densities at high levels, thereby increasing their impact on nontarget native species (Holt and Hochberg 2001). The importance of exotic plants in mediating the degree of nontarget attack of natives by biological control insects has not been investigated previously. We hypothesized that the presence of exotic thistles in a landscape would increase attack on cooccurring native thistles, compared with landscapes in which exotic thistles were absent or rare.

To examine whether changes to the landscape alter the susceptibility of native thistles to attack by $R$. con- 
icus, we quantified nontarget use by $R$. conicus of two native thistle species, Cirsium undulatum and $C$. flodmanii, in grassland patches within three landscape types: (1) agriculture (crop) dominated, (2) grassland dominated with exotic thistles, and (3) grassland dominated without exotic thistles. We addressed two sequential questions: (1) does the susceptibility of native thistles to attack by the biocontrol insect differ between landscape types, and, if so, (2) to what extent does exotic thistle density, either within a patch or in the surrounding matrix, predict the level of attack?

\section{Materials And Methods}

\section{Study system}

The study was done in the loess mixed grass prairie of central Nebraska, USA. The common thistle species in the region include one exotic, Carduus nutans L. (musk thistle), and two natives, Cirsium undulatum (Nutt.) Spreng. (wavyleaf thistle), and Cirsium flodmanii (Rydb.) Arthur (Flodman's thistle).

The weevil (Rhinocyllus conicus Fröl.) was introduced to the United States from Europe in 1969, and to Nebraska in 1969-1972, against exotic Eurasian thistles, especially the Carduus nutans complex (McCarty and Lamp 1982, Zwölfer and Harris 1984, Gassmann and Louda 2001). In the spring, overwintered adults of $R$. conicus mate and lay eggs on the bracts of developing thistle flower heads. After larvae hatch, they burrow into the receptacle, feed for 25-40 $\mathrm{d}$, and then pupate in hardened cells within the base of the flower head (Zwölfer and Harris 1984). In our region, $R$. conicus is univoltine.

\section{Selection of study areas}

South central Nebraska is comprised of a mosaic of agricultural and natural (primarily grassland/rangeland) habitats (Fig. 1A). Study areas were patches of prairie grassland $(800 \times 800 \mathrm{~m})$. Patches were embedded within a matrix composed of the eight surrounding $800 \times 800 \mathrm{~m}$ land parcels (Fig. 1B). Patch plus matrix areas together make up what we define as the landscape (total landscape area of $2.4 \times 2.4 \mathrm{~km}^{2}$ ). Grassland patches were identified using land-cover data from the National Land Cover Database (U.S. Geological Survey 2000), derived from 1992 Landsat Thematic Mapper satellite data. Potential grassland patches were selected in areas of high surrounding agricultural cover $(>50 \%$ crop cover in the matrix) or low agricultural cover $(<10 \%$ crop cover in the matrix). Within areas of low matrix agricultural cover, grassland patches were selected in landscapes with or without the exotic thistle (Carduus nutans). We consulted with county weed agents and used the Nebraska scoring system to identify landscapes "with $C$. nutans" in which at least two of the eight, $800 \times 800 \mathrm{~m}$, land parcels surrounding each patch were considered "moderately to severely" infested by exotic thistles ( $>200$ thistles/ha), and land- scapes "without $C$. nutans," which had no, or very low, densities $(<10$ thistles/ha) in any of the eight land parcels surrounding each patch. The replicate landscapes within each of the three landscape categories were independent, i.e., nonoverlapping (Fig. 1A).

To keep patch characteristics as similar as possible, we only selected grassland patches that had not been in agricultural use since at least 1971 (earliest landcover data available) and had no evidence of being overgrazed (average vegetation height $>20 \mathrm{~cm}$ ). Patches were also matched using major soil and climatic variables extracted from a GIS database (Milner et al. 2002). Sites were selected such that soil variables (based on data from USDA Soil Conservation Service [1994]) were held constant among all patches (root zone water holding capacity $=302 \mathrm{~mm}$; surfaceweighted soil organic matter $=1.9 \%$ ). Climate variables did not significantly differ between patches in different landscape types $(n=5$ patches per landscape type; one-way ANOVA: growing degree days, $F_{2,12}=$ $1.584, P=0.245$; average precipitation, $F_{2,12}=0.516$, $P=0.612$ ).

In the first year (2001), we located and sampled patches in grassland landscapes with or without exotic thistles ( $n=3$ replicates per landscape type). Both native thistle species were sampled within all six embedded patches. In the second year (2002), we increased the sample size ( $n=5$ replicates per landscape type) and included patches within an agriculturally dominated matrix ( $>50 \%$ crop cover). We were unable to locate both thistle species in all patches. We found C. undulatum in grassland patches within all except one agricultural landscape. C. flodmanii occurred in patches within all five agricultural landscapes, but only in three grassland landscapes with exotic thistles and in four without exotics.

\section{Measurement of thistle densities}

In 2002, we measured the density of bolting (flowering) individuals of both native and exotic thistle species within each patch and the density of exotic thistles in the surrounding matrix. Within patch thistle densities were measured by walking five $800 \mathrm{~m}$ long transects, $\sim 200 \mathrm{~m}$ apart, starting at each patch edge (Fig. 1B). All flowering $C$. nutans individuals were counted in a $30 \mathrm{~m}$ wide area ( $15 \mathrm{~m}$ to each side) along each transect. Because native thistles are much smaller and less obvious, we counted all bolting individuals of all thistle species in a $2 \mathrm{~m}$ wide band along each transect.

Densities of $C$. nutans in the surrounding matrix were estimated quantitatively by doing point counts at the corner of each patch, as well as three points (200 $\mathrm{m}$ apart) along each patch edge (total of 16 points; Fig. $1 \mathrm{~B})$. At each corner, the number of bolting exotic thistles was counted in a $100 \mathrm{~m}$ radius arc $\left(270^{\circ}\right)$ in the adjacent matrix, using binoculars. Similarly, at each edge point we counted all bolting $C$. nutans within a

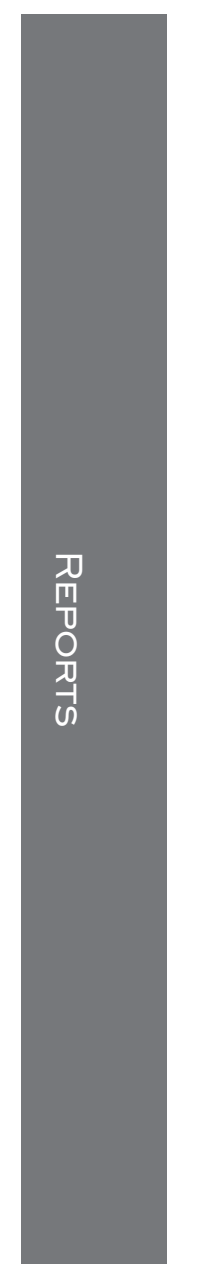



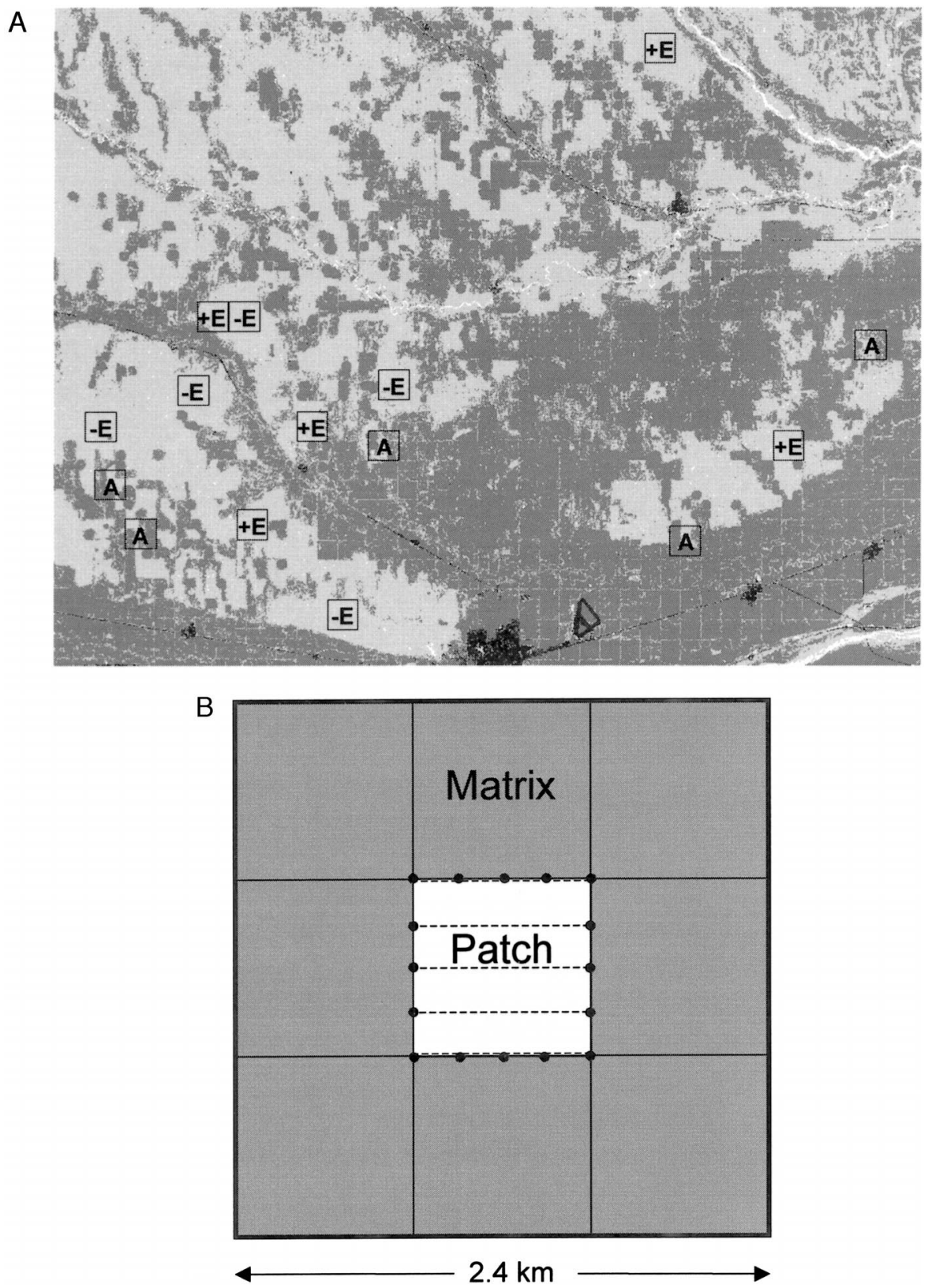

FIG. 1. (A) Layout of study landscapes in central Nebraska, USA. Light gray areas represent natural habitat, while dark gray areas represent crops. Study landscapes $(2.4 \times 2.4 \mathrm{~km})$ are indicated by black-outlined squares. Different letters represent different landscape types: A, agricultural; $+\mathrm{E}$, invaded by exotic thistle; $-\mathrm{E}$, not invaded by exotic thistle. (B) Schematic diagram of experimental landscapes composed of a central patch and the surrounding matrix. Dashed lines indicate the location of transects used to quantify within-patch thistle densities, while black points represent the location of point counts to estimate densities in the surrounding matrix.

semicircle $\left(180^{\circ}\right)$ of $100 \mathrm{~m}$ radius in the adjacent matrix.

\section{Egg density on native thistles}

Insect use of thistles within grassland patches was sampled intensively in the first half of July (2001, 2002) along transects initiated near a patch edge where plants had been observed previously. Thistles were measured as they were encountered at a minimum of $10 \mathrm{~m}$ apart. When thistles occurred in clusters, an individual was selected randomly. Total sample sizes were 10 Cirsium flodmanii and 25 C. undulatum individuals per patch in 2001, and 20 individuals for each species per patch where it was available in 2002, except for two sites where we were only able to find eight or 12 individuals of $C$. undulatum. 
For each thistle, we measured $R$. conicus egg load on three flower heads per plant: the primary terminal head, the first subsidiary head on the first branch, and the terminal head on the second branch. If one of the heads was unavailable for sampling (aborted or missing), we selected the next available branch terminal head (first or third branch). For each flower head, we also recorded diameter, flowering stage, and the number of $R$. conicus egg cases plus larval entrance holes as an estimate of the total number of eggs deposited per head.

\section{Statistical analyses}

The main response variable analyzed was the mean number of $R$. conicus eggs per head (egg load) for each plant species. These data could not be normalized, as many plants had no eggs. Thus, an analysis of variance (ANOVA) could not be used for the entire data set. As a result, we calculated a patch-level mean for $R$. conicus egg load for each native thistle species. Egg load data were power transformed $\left(x^{0.4}\right)$ prior to analysis to normalize distributions and meet assumptions of statistical models. We then used one-way ANOVA on patch means to test for differences in $R$. conicus egg load among landscape types. Planned contrasts were used to examine differences between two sets of landscapes in 2002. First, to examine influences of cultivated habitat on weevil attack, we contrasted agricultural landscapes vs. grassland landscapes without exotic thistles. Second, to examine the effect of exotic weed invasion on weevil attack, we contrasted grassland landscapes with vs. without exotic thistles. For 2002, we also calculated the frequency of $R$. conicus attack by scoring each plant at each site as having $R$. conicus eggs either present or absent.

Since $R$. conicus oviposits early in the growing season, egg load on the late-flowering C. flodmanii was very low (mostly zeros). Thus, detailed analyses for 2002 were carried out only for $C$. undulatum. Densities of the exotic musk thistle, Carduus nutans, at the patch and matrix levels were highly correlated $(r=0.76, P$ $=0.001, n=14)$, and could not be included in a single model. Thus, we ran separate univariate regressions to examine the effects of thistle density (patch $C$. nutans density, matrix $C$. nutans density, and patch $C$. undulatum density) on mean $R$. conicus egg load on $C$. undulatum, and on the proportion of $C$. undulatum plants attacked. In these analyses, independent variables were also transformed to minimize problems associated with influence and heteroscedasticity (Hamilton 1992). Thistle densities (both $C$. nutans and $C$. undulatum) were power transformed $\left(x^{0.3}\right)$ prior to analysis.

\section{RESUlts}

Although the exotic thistle, Carduus nutans, was present at very low densities in landscapes that had been classified as "exotic free," densities were more than an order of magnitude higher in landscapes categorized
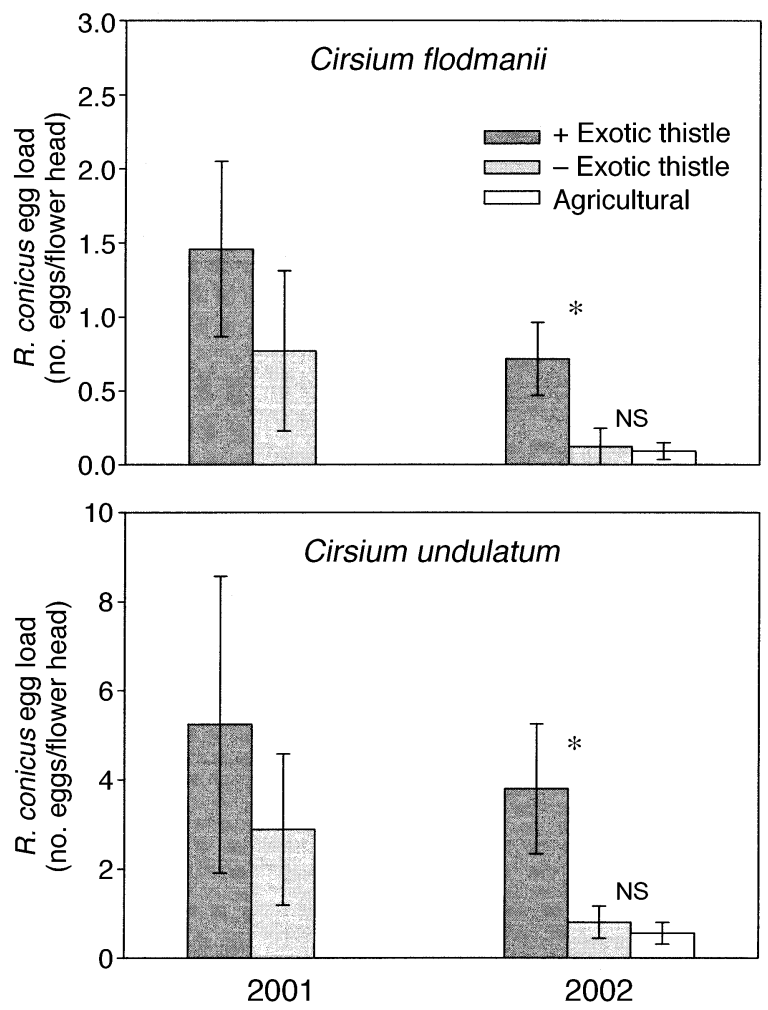

FIG. 2. Rhinocyllus conicus egg load (untransformed means $\pm 1 \mathrm{SE}$ ) on the two native thistle species in grassland patches within two landscape types in 2001, and three landscape types in 2002. Results of planned contrasts comparing landscape pairs are presented above bars for 2002 (NS = not significant; $* P<0.05$ ).

as having exotic thistles present, both within patches and within the surrounding matrix (mean density \pm 1 $\mathrm{SE}$; patch $=111.26 \pm 59.00$ plants $/$ ha, matrix $=72.76$ \pm 22.7 plants/ha, $n=5$ ) vs. absent (patch $=0.45 \pm$ 0.28 plants/ha, matrix $=3.83 \pm 2.10$ plants/ha, $n=$ 5). Patch and matrix $C$. nutans densities in agricultural landscapes were similar to those in uninvaded grassland landscapes (patch density $=2.38 \pm 1.04$ plants/ ha, matrix density $=4.54 \pm 4.15$ plants/ha, $n=4$ ).

We found that $R$. conicus eggs were present at all six sites in 2001 and 12 of 15 sites in 2002. Egg densities were generally higher in 2001 than 2002, and much higher on C. undulatum than on C. flodmanii (Fig. 2). Egg load also differed among landscape types in both years (Fig. 2). In 2001, mean $R$. conicus egg density on the two native species was almost twice as great in patches within landscapes with exotic thistles than within landscapes with extremely low densities of the exotic thistle. Given the variability observed, however, these differences were not statistically significant for either species (one-way ANOVA: $C$. flodmanii, $F_{1,4}=$ $0.722, P=0.443 ; C$. undulatum, $F_{1,4}=0.215, P=$ $0.667)$. Low replication in $2001(n=3$ replicates per landscape type) likely contributed to this result. 
In 2002, the pattern was stronger. Egg densities were more than four times higher in landscapes that contained exotic thistles than in those with very low densities of exotic thistles; differences in egg loads between landscape types were clearly significant for $C$. flodmanii and marginally so for $C$. undulatum (oneway ANOVA: $C$. flodmanii, $F_{2,9}=4.664, P=0.041$; C. undulatum, $F_{2,11}=3.434, P=0.069$; Fig. 2). Planned contrasts showed that (1) $R$. conicus egg load on native thistles was significantly higher in grassland landscapes invaded by exotic thistles relative to those with low densities of exotic thistles, and (2) there was no difference in $R$. conicus egg load on native thistles in patches within grassland landscapes with low densities of exotic thistles compared with intensive agricultural landscapes (Fig. 2).

The percentage of $C$. undulatum plants attacked was almost twice as high in grassland landscapes invaded by $C$. nutans $(52 \%)$ than in either grassland landscapes without $C$. nutans (28\%) or agricultural landscapes (22\%), paralleling the pattern observed for egg load. Similarly, for C. flodmanii the percentage of plants attacked was five times higher in grassland landscapes invaded by $C$. nutans $(25 \%)$ than either in grassland landscapes without $C$. nutans $(4.5 \%)$ or agricultural landscapes $(5 \%)$.

The influence of thistle densities on $R$. conicus egg load on $C$. undulatum depended upon the thistle species. The density of $C$. undulatum, measured within a patch, did not have a significant effect on the average egg load it received (Fig. 3). However, R. conicus egg load on $C$. undulatum increased significantly with increasing densities of $C$. nutans, measured at both the patch and matrix levels (Fig. 3). Within-patch C. nutans density was the best predictor, explaining more than $50 \%$ of the site-to-site variation in egg load on C. undulatum in 2002 (Fig. 3). Similarly, the proportion of $C$. undulatum plants attacked by $R$. conicus increased significantly with increasing patch $C$. nutans density $\left(R^{2}=0.49, P=0.005, n=14\right)$, but matrix $C$. nutans density had no significant effect $(P=0.14)$, nor did patch $C$. undulatum density $(P=0.43)$.

\section{DISCUSSION}

Overall, the susceptibility of native thistles, C. undulatum and $C$. flodmanii, to attack by the exotic weevil $R$. conicus differed among landscape types. This effect could be explained largely by associated differences in patch-level densities of exotic thistles.

Egg load on native thistles did not differ significantly between patches within the agriculturally dominated landscapes and patches within grassland landscapes that had similarly low densities of exotic thistles. Thus, other factors likely associated with agricultural intensification, such as reduction in the landscape-level abundance of native host plants or increasing habitat discontinuity, do not appear to be important determinants of weevil attack on native plants. This result con-
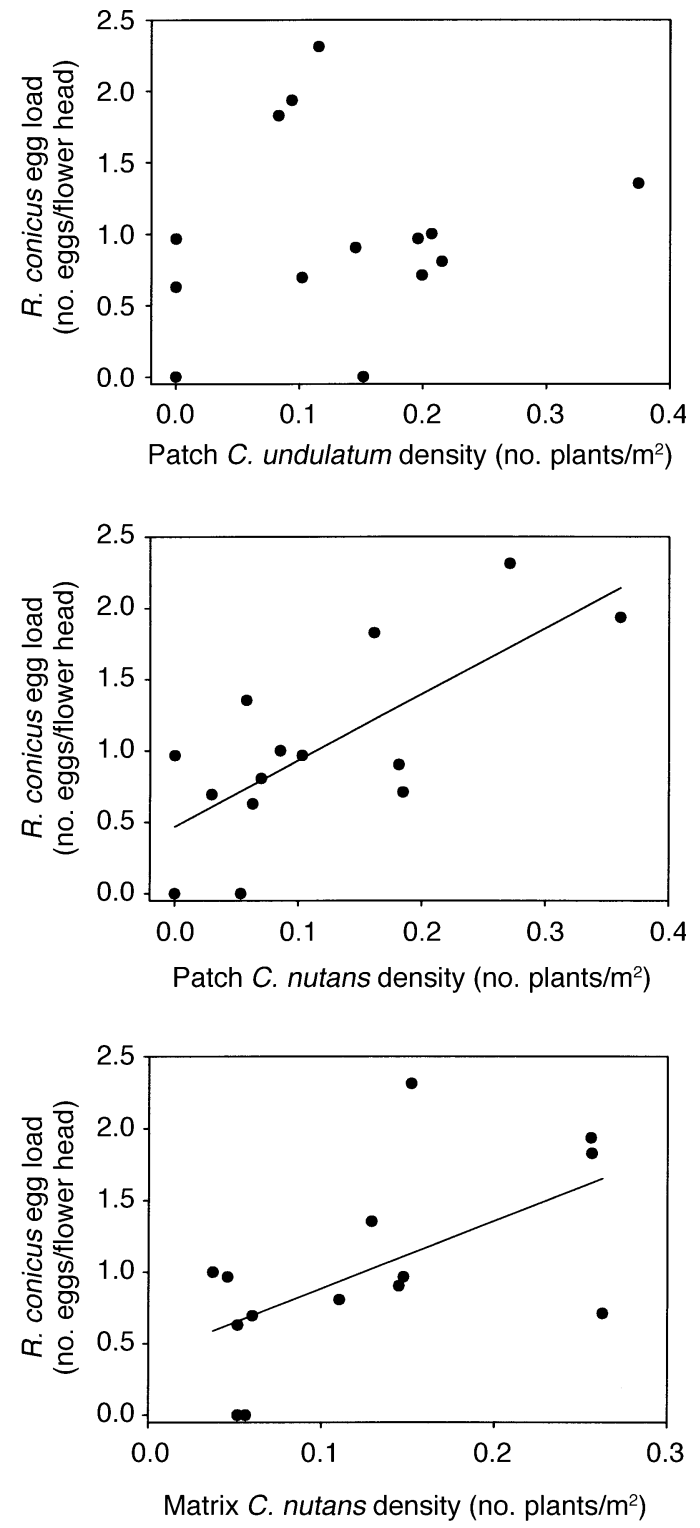

FIG. 3. Rhinocyllus conicus egg load on the native thistle, Cirsium undulatum, in relation to patch-level conspecific density $\left(R^{2}=0.02, F_{1,12}=0.23, P=0.639\right)$, patch-level Carduus nutans density $\left(R^{2}=0.53, F_{1,12}=13.56, P=0.003\right)$, and matrix-level $C$. nutans density $\left(R^{2}=0.34, F_{1,12}=6.28, P=\right.$ $0.028)$. Transformed data are plotted for both thistle density $\left(x^{0.3}\right)$ and $R$. conicus egg load $\left(y^{0.4}\right)$.

trasts with previous studies demonstrating a reduction in levels of damage by seed-feeding insects as the proportion of natural habitat decreases within a landscape (Steffan-Dewenter et al. 2001), or as distance between host plant patches increases (Kruess and Tscharntke 1994). The disparity in results may reflect the fact that the agricultural landscapes in this study still contained $25-40 \%$ natural habitat, which is higher than that reported in previous studies where significant effects were found (Steffan-Dewenter et al. 2001). 
Exotic thistle invasion strongly increased native plant susceptibility to herbivory. Both the intensity (mean egg load) and frequency (proportion of plants damaged with eggs) of attack by $R$. conicus were much higher (two- to fivefold) on native thistles within grassland landscapes that contained large populations of the exotic thistles than in those with low densities. This pattern was consistent both across species and years, suggesting its robustness. More detailed analysis revealed that $R$. conicus egg load on $C$. undulatum increased significantly with increases in both patch and matrix densities of the exotic thistle. However, since patch and matrix densities were correlated, it was not possible to separate the relative importance of each. Patch density explained more of the variation (53\%) in $R$. conicus egg load on native thistles, however, and it was the only significant predictor of the frequency of attack. In contrast to the strong effects of exotics, patch-level densities of native conspecific thistles $(C$. undulatum) had no significant effect on either weevil egg load or the frequency of attack. Thus, in this system, $R$. conicus dynamics appear to be strongly linked to densities of the exotic rather than the native thistles.

Weevil feeding and larval development dramatically reduce seed production in early flowering native species, including $C$. canescens and $C$. undulatum, since $R$. conicus is active over the majority of their flowering period (Louda 1999). For example, seed production of C. undulatum is reduced by more than $80 \%$ in flower heads with $R$. conicus feeding compared to those without (Louda 1999), and weevil egg load is significantly negatively correlated with seed production for flower heads of a given size $(r=-0.24, P<0.0001$; S. M. Louda, unpublished data). In addition, nontarget feeding by $R$. conicus has led to severe declines in the population densities of the native, Cirsium canescens Nutt. (Louda et al. 2003a), and also likely impacts $C$. undulatum in sand prairie (Louda 1999). Thus, increased attack of $C$. undulatum within patches or landscapes invaded by exotic thistles will likely impact populations of this native thistle. To our knowledge, these results provide the first empirical evidence that invasion by an exotic plant can increase the attack of, and thus potential impact on, a native plant by a shared exotic herbivore. We conclude that the exotic plant has the potential to exert a strong negative, indirect effect on related native plant species.

The results parallel those of previous studies demonstrating that shared herbivores can generate negative indirect interactions between native plant species (Parker and Root 1981, Rand 2003). The findings also are consistent with theoretical models, which predict that prey species that share a common predator can have indirect negative effects on each other's population dynamics, i.e., experience "apparent competition" (Holt 1977). Finally, the data support the suggestion by Simberloff and Von Holle (1999) that nonindigenous species may facilitate one another's invasion, thereby increasing the likelihood and magnitude of ecological impacts on native species. Our results suggest that $R$. conicus is facilitated by the presence of the exotic thistle, and past studies confirm that it is often limited in its ability to reduce weed population densities (Gassmann and Louda 2001). Thus, persistent exotic thistle populations appear to serve as a "reservoir" of $R$. conicus, magnifying both the intensity and frequency of the weevil's attack on associated native thistles.

The danger associated with nontarget feeding by biological control agents is widely recognized (Turner et al. 1987, Louda et al. 2003b). What is less obvious is that the magnitude of the threat posed to nontarget species can be determined largely by the dynamics of the control agent-target weed interaction (Holt and Hochberg 2001), as appears to be the case here. In situations where the control agent imposes only moderate to little control over its target prey species, the exotic plant can remain sufficiently abundant to support large herbivore populations, resulting in "spillover" onto nontarget native species with potentially serious ecological consequences (Holt and Hochberg 2001). A relatively small percentage $(20 \%)$ of weed biological control insect introductions show evidence of significant quantitative limitation of the targeted weed population (Williamson and Fitter 1996). Thus, in many cases, abundant weed populations and their associated exotic insects may remain in the environment. This combination creates the potential for negative, synergistic effects on native species, such as those documented in this study.

A number of other factors, including host-plant phenology and herbivore feeding preferences, may additionally influence the intensity of nontarget effects (Louda et al. 2003b). We found that levels of attack of the late-flowering native species $C$. flodmanii were much lower than on $C$. undulatum, which flowers synchronously with the time when $R$. conicus is active. This result suggests that reduced temporal overlap between plants and insects is likely to decrease the intensity of spillover effects. Herbivore feeding preferences for a given plant species can in some cases reduce use of less preferred host species in agricultural systems (Atsatt and O'Dowd 1976). Thus, preference of biocontrol herbivores for targeted host plants might also be expected to reduce levels of attack on native species. However, we found substantial use of the native $C$. undulatum in landscapes invaded by the exotic despite a previously documented preference for, and increased performance on, Carduus nutans over most Cirsium spp. (Zwölfer and Harris 1984, Gassmann and Louda 2001). Thus, clearly even less preferred hostplant species are at risk from spillover effects. Although spillover is generally considered a minor problem in weed biological control (Blossey et al. 2001), we suggest that the conditions under which it poses a threat need to be evaluated much more extensively.

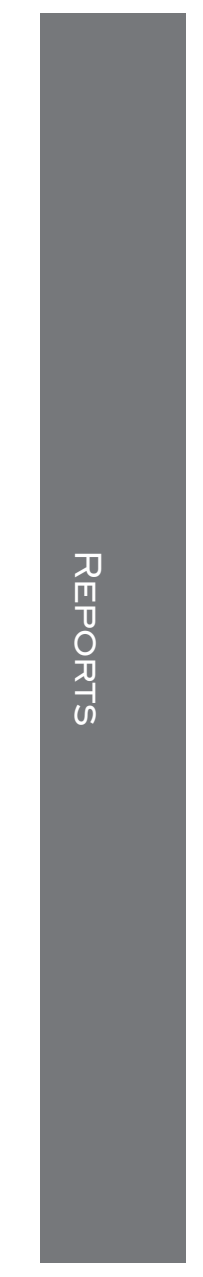


In conclusion, our results demonstrate that when exotic plants support insect herbivores that also feed on natives, they can increase the intensity and frequency of herbivore attack on native plants. The study underscores the importance of incorporating indirect effects into studies of invasion dynamics. In addition, the data suggest that over the long term, patch to landscapescale reductions in exotic plant densities could benefit related, co-occurring, native species by decreasing population densities of exotic herbivores. Finally, the evidence that spillover can result in substantial use of some native species suggests that managers should exercise great caution when considering the release of control agents if there is any evidence that native species within targeted natural areas may serve as even secondary hosts.

\section{ACKNOWLEDGMENTS}

We thank Sharon Collinge, Todd Minchinton, and Leland Russell for insightful comments on the manuscript. Haishin Ozawa and Shauna Hawkins provided invaluable field assistance. Dave Mortensen, Maribeth Milner, and Patti Dappen provided GIS data and support. We are additionally grateful to the numerous individuals who generously granted us permission to work on their property. This research was funded by a D. H. Smith Conservation Research Fellowship from The Nature Conservancy to T. A. Rand. Additional support was provided by a USDA-NRI grant (\#2001-35320-09882) to S. M. Louda. This is publication no. DHS2004-01 of the Nature Conservancy's David H. Smith Conservation Research Fellowship Program.

\section{Literature Cited}

Atsatt, P. R., and D. J. O'Dowd. 1976. Plant defense guilds. Science 193:24-29.

Blossey, B., R. Casagrande, L. Tewksbury, D. A. Landis, R. N. Wiedenmann, and D. R. Ellis. 2001. Nontarget feeding of leaf-beetles introduced to control purple loosestrife (Lythrum salicaria L.). Natural Areas Journal 21:368-377.

DeBach, P., and D. Rosen. 1990. Maximizing biological control through research. Pages 259-302 in P. DeBach and D. Rosen, editors. Biological control with natural enemies. Cambridge University Press, New York, New York, USA.

Gassmann, A., and S. M. Louda. 2001. Rhinocyllus conicus: initial evaluation and subsequent ecological impacts in North America. Pages 147-183 in E. Wajnberg, J. K. Scott, and P. C. Quimby, editors. Evaluating indirect ecological effects of biological control. CABI Publishing, Wallingford, Oxon, UK.

Hamilton, L. C. 1992. Regression with graphics: a second course in applied statistics. Wadsworth, Belmont, California, USA.

Higgins, S. I., D. M. Richardson, R. M. Cowling, and T. H. Trinder-Smith. 1999. Predicting the landscape-scale distribution of alien plants and their threat to plant diversity. Conservation Biology 13:303-313.

Hobbs, R. J. 2001. Synergisms among habitat fragmentation, livestock grazing, and biotic invasions in southwestern Australia. Conservation Biology 15:1522-1528.

Holt, R. D. 1977. Predation, apparent competition and the structure of prey communities. Theoretical Population Biology 12:197-229.

Holt, R. D., and M. E. Hochberg. 2001. Indirect interactions, community modules and biological control: a theoretical perspective. Pages 13-37 in E. Wajnberg, J. K. Scott, and P. C. Quimby, editors. Evaluating indirect ecological effects of biological control. CABI Publishing, Wallingford, Oxon, UK.
Janzen, D. H. 1983. No park is an island: increase interference from outside as park size decreases. Oikos 41:402-410.

Kruess, A., and T. Tscharntke. 1994. Habitat fragmentation, species loss, and biological control. Science 264:15811584.

Louda, S. M. 1999. Negative ecological effects of the musk thistle biocontrol agent, Rhinocyllus conicus Fröl. Pages 215-243 in P. A. Follet and J. J. Duan, editors. Nontarget effects of biological control. Kluwer Academic Publishers, Boston, Massachusetts, USA.

Louda, S. M., A. E. Arnett, T. A. Rand, and F. L. Russell. $2003 a$. Invasiveness of some biological control insects and adequacy of their ecological risk assessment and regulation. Conservation Biology 17:73-82.

Louda, S. M., R. W. Pemberton, M. T. Johnson, and P. A. Follett. 2003b. Nontarget effects-the Achilles' heel of biological control? Retrospective analyses to reduce risk asociated with biocontrol introductions. Annual Review of Entomology 48:365-396.

MacArthur, R. H., and E. O. Wilson. 1967. The theory of island biogeography. Princeton University Press, Princeton, New Jersey, USA.

McCarty, M. K., and W. O. Lamp. 1982. Effect of a weevil, Rhinocyllus conicus, on Musk Thistle (Carduus thoermeri) seed production. Weed Science 30:136-140.

Milner, M., D. A. Mortensen, K. G. Cassman, and W. J. Waltman. 2002. Geospatial applications for Nebraska agriculture. CD 6. University of Nebraska Cooperative Extension, University of Nebraska, Lincoln, Nebraska, USA.

National Research Council. 2002. Predicting invasions of nonindigenous plants and plant pests. National Academy Press, Washington, D.C., USA.

Parker, M. A., and R. B. Root. 1981. Insect herbivores limit habitat distribution of a native composite, Macheranthera canescens. Ecology 62:1390-1392.

Rand, T. A. 2003. Herbivore mediated apparent competition between two salt marsh forbs. Ecology 84:1517-1526.

Simberloff, D., and B. Von Holle. 1999. Positive interactions of nonindigenous species: invasional meltdown? Biological Invasions 1:21-32.

Smallwood, K. S. 1994. Site invasibility by exotic birds and mammals. Biological Conservation 69:251-259.

Steffan-Dewenter, I., U. Munzenberg, and T. Tscharntke. 2001. Pollination, seed set and seed predation on a landscape scale. Proceedings of the Royal Society of London Series B 268:1685-1690.

Suarez, A. W., D. T. Bolger, and T. J. Case. 1998. Effects of fragmentation and invasion on native ant communities in coastal southern California. Ecology 79:2014-2056.

Turner, C. E., R. W. Pemberton, and S. S. Rosenthal. 1987. Host utilization of native Cirsium thistles (Asteraceae) by the introduced weevil Rhinocyllus conicus (Coleoptera: Curculionidae) in California. Environmental Entomology 16:111-115.

USDA Soil Conservation Service. 1994. State soil geographic database (STATSGO) user's guide. Miscellaneous Publication No. 1492. National Soil Survey Center, Lincoln, Nebraska, USA.

U.S. Geological Survey. 2000. Nebraska land cover data set. U.S. Geological Survey, Sioux Falls, South Dakota, USA.

Wilcove, D. S., D. Rothstein, J. Dubow, A. Phillips, and E. Losos. 1998. Quantifying threats to imperiled species in the United States. BioScience 48:607-615.

Williamson, M., and A. Fitter. 1996. The varying success of invaders. Ecology 77:1661-1666.

With, K. A. 2002. The landscape ecology of invasive spread. Conservation Biology 16:1192-1203.

Zwölfer, H., and P. Harris. 1984. Biology and host specificity of Rhinocyllus conicus (Froel.) (Col., Curculionidae), a successful agent for biocontrol of the thistle, Carduus nutans L. Zeitschrift der Angewandte Entomologie 97:36-62. 